\title{
Structural Diversity in Organotin(IV) Carboxylates: A Study of X-Ray Crystallography
}

\author{
GARIMAMATELA $^{1}$, ROBINAAMAN $^{2 *}$ and NAGMANAZ ${ }^{2}$ \\ ${ }^{1}$ Department of Chemistry, Kumaun University, GDC Jainti, Almora-263626, India \\ ${ }^{2}$ Department of Chemistry, Kumaun University, S.S.J.Campus Almora-263601, India \\ *amanrobina@yahoo.com
}

Received 22 May 2019 / Accepted 30 June 2019

\begin{abstract}
Among the organotin compounds, organotin(IV) carboxylates adapt a fascinating range of structural diversity, including monomer, dimer, tetramer, polymer, oligomer ladder, cyclic and hexameric drums structures. Generally four- and five coordinated complexes are observed in triorganotin(IV) complexes. While diorganotin(IV) complexes displayed a large range of structures, including five, six and seven coordinate geometries with distorted trigonalbipyramidal, octahedral and pentagonal bipyramidal structures. Distannoxanes complexes are also observed in diorganotin(IV) complexes. A comprehensive review, organotin(IV) carboxylates are presented with particular reference to their structural studies as described bycrystallography methods.
\end{abstract}

Keywords: Organotin(IV) Carboxylate, Structural Chemistry, X-Ray crystallography

\section{Introduction}

The organotin(IV) carboxylates have been known due to its versatile and significant important biological activities ${ }^{1-10}$. A number of studies have been done on organotin(IV) carboxylates by various spectroscopic studies and the molecular structure of these complexes have described by $x$-ray crystallography ${ }^{11,12}$. Organotin(IV) carboxylates have been known due to its notable and vast structural diversity ${ }^{8,9,13-16}$. Interesting tin chemistry has been observed in organotin(IV) carboxylate with different coordination sphere at tin atom. Generally five- and six coordinated organotin(IV) complexes are observed with trigonalbipyramidal and octahedral geometry, respectively. Four- and seven coordinated geometry have also been observed in tricyclohexyltin ${ }^{17}$ and trinuclear di- $n$-butyltin(IV) complexes $^{18}$, respectively. Yip et al., ${ }^{19}$ and A. Rehman et al. ${ }^{20}$ have also synthesized fourcoordinatedtriorganotin(IV), complexes bis[triphenyltin(IV)] succinate and (3-amino-4chlorobenzoato)trimethyltin(IV), respectively, with monoclinic crystal system and monodentate bonding of the carboxylate group to the tin atom.

Amini et al., have synthesized bis(benzoato) ethyl phenyltin(IV) by the reaction of ethyldiphenyltin(IV) iodide with silver benzoate in ethanol, by the cleavage of a phenyl 
group bound to tin and suggested a skew-trapezoidal bipyramidal structure. A cyclic hexamer structure of triorganotin carboxylates, ethyldiphenyltin(IV) acetate and diphenylpropyltin(IV) acetate has also been determined by them ${ }^{21}$. Trimethyltin(IV) 2,3-methylenedioxy benzoate has been synthesized by Hussain et al. It has been found that the structure is tetrahedral for triorganotin(IV) complex, in solution state. While in the solid state, triorganotin(IV) complex showed the distorted trigonal bipyramidal geometry ${ }^{22}$. The di- and triorganotin(IV) complexes with $n$-butylhydrogen phthalate have been synthesized by the reaction of corresponding organotin(IV) oxide with $n$-butylhydrogen phthalate in dry toluene. A distorted octahedral geometry was found for diorganotin(IV) derivatives and triorganotin(IV) $n$-butylphthalates adopt linear, polymeric trigonalbipyramidal geometry in which $n$-butylphthalate is a monoanionicbidentate coordinating through the $\mathrm{C}(\mathrm{O}) \mathrm{O}$ group $^{23}$.

The coordination sphere at tin atom also plays a significant role in their important biological activities. Win et al., have synthesized organodistannoxane dimer complexes derived from alkylaminobenzoic acids. In these complexes carboxylate anions acted as monoand bidentate ligand ${ }^{24}$. These complexes have been found active against human liver carcinoma cells (HepG2), in which bis[2-(methylamino)benzoato] tetrabutyldistannoxane(IV) dimer showed significant activity. Sun et al.,25 have synthesized polynuclear phenyl- and butyltin(IV) carboxylates having ladder and drum structures and showed anti-tumor activities against HepG2 human hepatocellular liver carcinoma cells, A549 human lung carcinoma cells and B16-F10 melanoma cells. Among these complexes a centrosymmetricphenyltin(IV) complex exhibited the best cytotoxicity. A trimethyltin(IV) complex derived from 2,6dimethoxypyridine-3-carboxylic acid has also displayed significant anti-tumor activities against human adenocarcinoma HeLa, human myelogenous leukaemia K562, human malignant melanoma Fem-x and human breast carcinoma MDA-MB-361 ${ }^{26}$. Shukla et al., ${ }^{27}$ have investigated significant antitumor, antibacterial, antifungal and insecticidal activity of some triorganotin(IV) carboxylates. Organotin(IV) complexes with $n$-butylhydrogen phthalate $^{28}$ and 2-(N-Maleoylamino)-2-methylpropanoate ${ }^{29}$ also displayed remarkable antibacterial and antifungal activity against various pathogenic strains. Keeping in mind a vast structural diversity of organotin(IV) carboxylates, an attempt is being made in this article to present a brief up to date review on the organotin(IV) carboxylates with special reference to their structural chemistryas determined by crystallographicmethods.

\section{Structural chemistry of organotin(IV) carboxylates}

In organotin(IV) carboxylates, carboxylate group of ligand coordinates to the tin atom in monodentate or bidentate fashion in different stochiometries and leads to a different coordination sphere at tin atom. This section will be discuss as seven-, six-, five-, fourcoordinated complexes and distannoxanes.

\section{Seven coordinated complexes}

In organotin complexes, distorted pentagonal bipyramidal geometry results by asymmetrical coordination of the carboxylate ligands to the $\mathrm{Sn}$ atom. A representative structure is given in Figure 1. A centrosymmetric dimer is observed in the complex, $\left\{\left[\mathrm{Ph}_{2} \mathrm{Sn}\left(2,6-\mathrm{C}_{5} \mathrm{H}_{3} \mathrm{~N}\right)\right.\right.$ $\left.(\mathrm{COO})]\left[\mathrm{Na}\left(2,6 \mathrm{C}_{5} \mathrm{H}_{3} \mathrm{~N}\right)(\mathrm{COOH})(\mathrm{COO})\left(\mathrm{CH}_{3} \mathrm{OH}\right)_{2}\right]\right\}$. The coordination sphere of each tin atom is $\mathrm{N}_{1} \mathrm{O}_{4} \mathrm{C}_{2}$ in a distorted pentagonal bipyramidal, with two phenyl groups are trans to each other (C-Sn-C angle of $167.52(8)^{\circ}$ ) (Figure 1). Each tin atom is coordinated by two monodentate and one bidentate carboxylate group ${ }^{30}$. Salam et al.,$^{18}$ have also synthesized a seven coordinated tri-nuclear di- $n$-butyltin(IV) complex of pyruvic acid- $N(4)$ - cyclohexyl- 
thiosemicarbazone in distorted pentagonal bipyramidal geometry. The central tin(IV) atoms are bonded to carboxylato-O, the azomethine- $\mathrm{N}$ and the thiolato-S atoms of ligand and bridges between the tin atoms are formed through the carbonyl oxygen atom of the carboxylate groups. They have reported that crystal of this complex is cubic with space group $I-4_{3} d, a=b=c=30.3273(17) \AA, \alpha=\beta=\gamma=90^{\circ}, Z=16$ and final $R_{1}=0.0390$, $w R_{2}=0.0843$ for observed reflections $4582(I>2 \sigma(I))$.

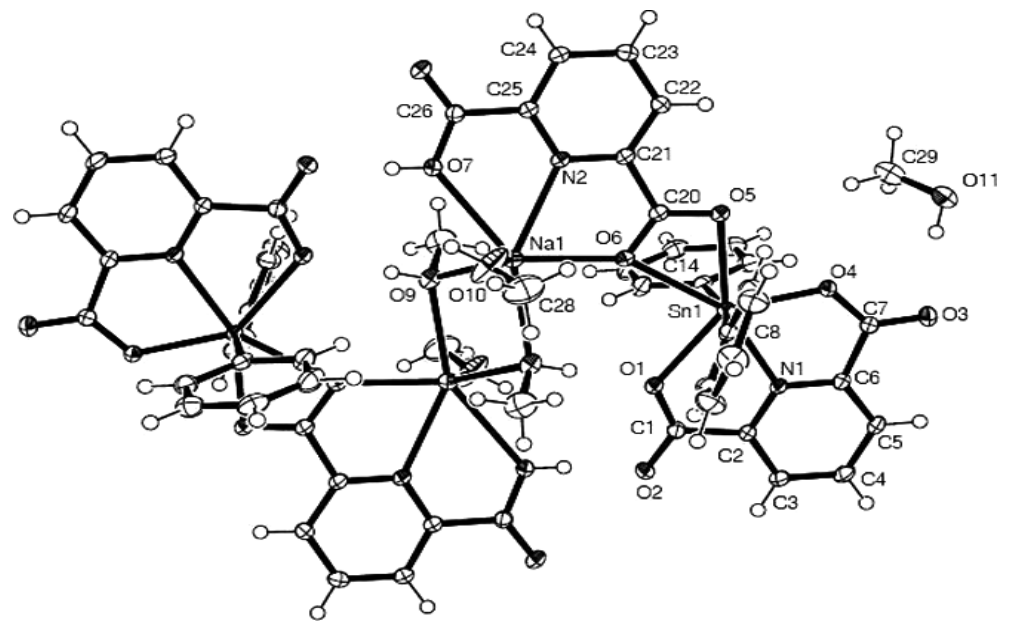

Figure 1. Molecular structure of complex $\left\{\left[\mathrm{Ph}_{2} \mathrm{Sn}\left(2,6 \mathrm{C}_{5} \mathrm{H}_{3} \mathrm{~N}\right)(\mathrm{COO})\right]\left[\mathrm{Na}\left(2,6 \mathrm{C}_{5} \mathrm{H}_{3} \mathrm{~N}\right)(\mathrm{COOH})\right.\right.$ $\left.\left.(\mathrm{COO})\left(\mathrm{CH}_{3} \mathrm{OH}\right)_{2}\right]\right\}$

\section{Six coordinated complexes}

A distorted octahedral geometry is found in six coordinated complexes as shown in Molecular structure of complex $\left[\mathrm{Me}_{2} \mathrm{Sn}\left(2,6-\mathrm{C}_{5} \mathrm{H}_{3} \mathrm{~N}\right)(\mathrm{COO})_{2}\left(\mathrm{H}_{2} \mathrm{O}\right)\right] \cdot \mathrm{H}_{2} \mathrm{O}$ (Figure 2). The crystal and molecular structure of $\left[\mathrm{Me}_{2} \mathrm{Sn}\left(2,6-\mathrm{C}_{5} \mathrm{H}_{3} \mathrm{~N}\right)(\mathrm{COO})_{2}\left(\mathrm{H}_{2} \mathrm{O}\right)\right] \cdot \mathrm{H}_{2} \mathrm{O}$ has been determined by A. Azadmeher et al., ${ }^{30}$. The tin atom, bonding to two methyl carbons (Sn1-C8 2.092(5), Sn1-C9 2.085(5) A; C9-Sn1-C8 164.8(2) ), two carboxylate oxygen atoms (Sn1O1 2.435(3), Sn1-O2 2.182(3) Å; O2-Sn1-O1 139.14(11) ${ }^{\circ}$, pyridine nitrogen (Sn1-N1 2.287(4) $\AA$ ) and a water molecule (Sn1-O1W 2.300(3) $\AA$ ) has a distorted octahedral geometry (Figure 2).

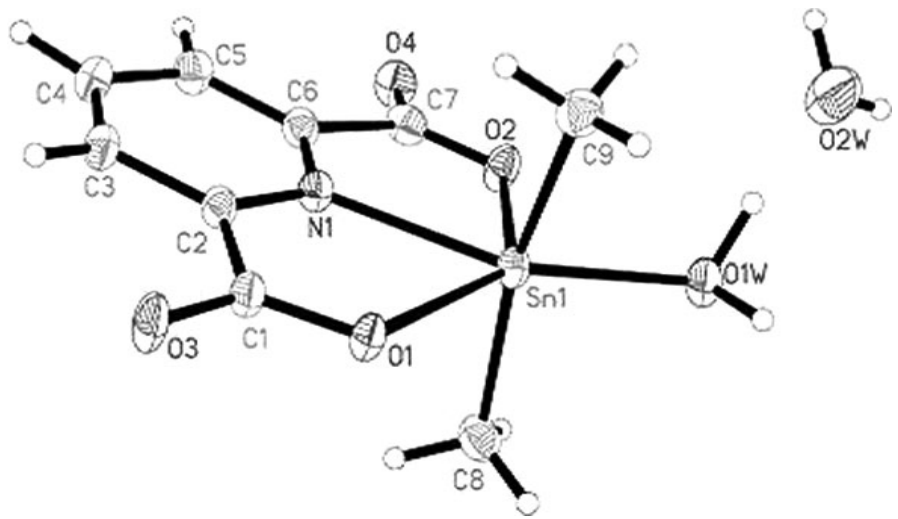

Figure 2. Molecular structure of complex $\left[\mathrm{Me}_{2} \mathrm{Sn}\left(2,6-\mathrm{C}_{5} \mathrm{H}_{3} \mathrm{~N}\right)(\mathrm{COO})_{2}\left(\mathrm{H}_{2} \mathrm{O}\right)\right] \cdot \mathrm{H}_{2} \mathrm{O}$ 
Amini et $a l .{ }^{21}$ have reported that crystal of ethylphenyltin(IV) dibenzoate $\mathrm{PhEtSn}\left[\mathrm{OC}(\mathrm{O}) \mathrm{C}_{6} \mathrm{H}_{5}\right]_{2}$ is triclinic with space group $P 1 \quad(\mathrm{a}=8.6426(18), \mathrm{b}=10.472(2), \mathrm{c}=$ $11.520(2) \AA ; \alpha=83.594(16)^{\circ}, \beta=76.512(16)^{\circ}, \quad \sigma=87.126(17)^{\circ} ; Z=2, D_{\text {calc }}\left(\mathrm{g} \mathrm{cm}^{-3}\right)=1.540$, $\left.R_{\text {int }}=3935(0.021)\right)$. A skew-trapezoidal bipyramidal geometry, with the two organic groups in the pseudo-axial positions towards the weaker equatorial Sn-O interactions is observed in the complex (Figure 3). A skew-trapezoidal planar geometry is also observed in a Di- $n$ butyltin(IV) bis- [2,3-bis (4-chlorophenyl)propenoato-O,O] complex ${ }^{31}$.

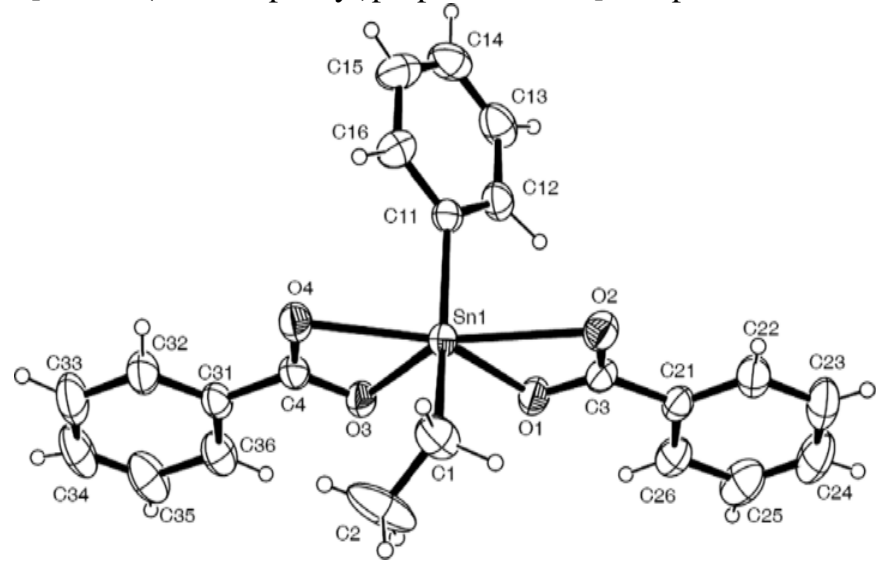

Figure 3. Molecular structure of complex $\mathrm{PhEtSn}\left[\mathrm{OC}(\mathrm{O}) \mathrm{C}_{6} \mathrm{H}_{5}\right]_{2}$

Baul et al., ${ }^{32}$ have studied x-ray crystal structure of triphenyltin(IV) complex derived from carboxylate ligand, potassium $\beta-\{[(\mathrm{E})-1-(2 \mathrm{hyd} d r o x y p h e n y l) m e t h y l i d e n e]$ amino $\}$ propionate. A one-dimensional polymeric structure is observed with two Sn-atoms with distinct coordination environments. The $\mathrm{SnPh}_{3}$ moieties are linked by two modes of bridging alternating along the polymeric chain (Figure 4).

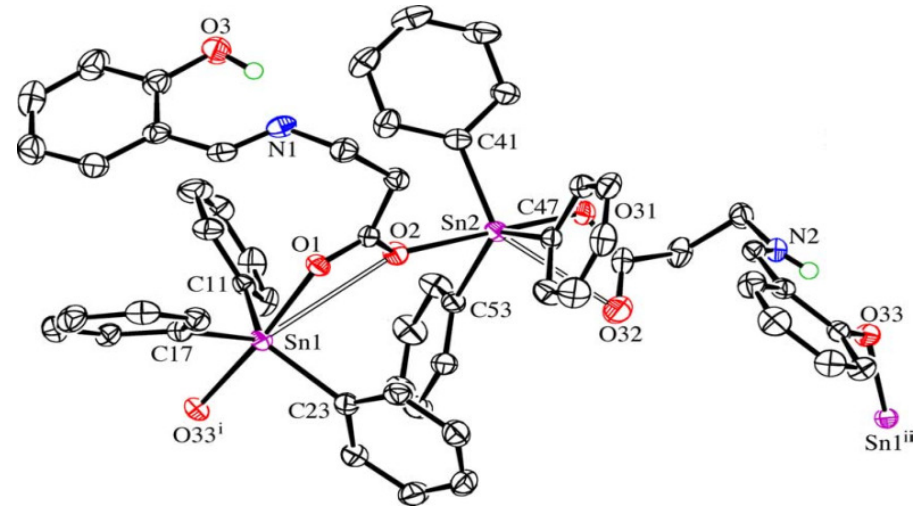

Figure 4. The unique repeat unit in the polymeric chain structure of $\left[\mathrm{Ph}_{3} \mathrm{SnHL}_{\mathrm{n}}(50 \%\right.$ probability ellipsoids)

The coordination sphere of $\mathrm{Sn}(1)$ is $\mathrm{C}_{3} \mathrm{O}_{3}$, with three phenyl groups, a carboxylate $O$-atom from one carboxylate ligand and the phenoxide $O$-atom from a second carboxylate ligand, and second carboxylate $O$-atom of former carboxylate ligand, which coordinates strongly to $\operatorname{Sn}(2)$, also has a weak interaction with $\operatorname{Sn}(1)(\operatorname{Sn} . . \mathrm{O}=3.202(3) \AA)$ and completing six coordination at $\operatorname{Sn}(1)$. While the same coordination sphere of $\operatorname{Sn}(2)$ is built 
with three phenyl groups, a carboxylate $O$-atom from one carboxylate ligand and two carboxylate $O$-atoms from a second carboxylate ligand $(\mathrm{Sn}(2)-\mathrm{O}(2)=2.396(3), \operatorname{Sn}(2)-\mathrm{O}(31)=$ $2.148(3), \operatorname{Sn}(2) \ldots \mathrm{O}(32)=2.986(3) \AA)$.

\section{Five coordinated complexes}

Among the organotin(IV) complexes, triorganic complexes form a polymeric structure with trigonal bipyramidal geometry ${ }^{22,32,33}$. Monomer tructures are also observed in tribenzyltin(IV) derivatives ${ }^{34,35}$. A trigonal bipyramidal geometry is also observed in dimethyltin(IV) complex, $\left\{\mathrm{Me}_{2} \mathrm{Sn}\left[\mathrm{OC}(\mathrm{O})\left(\mathrm{C}_{14} \mathrm{H}_{9}\right)\right]_{2} \cdot \mathrm{CH}_{3} \mathrm{OH}\right\} \mathrm{CH}_{3} \mathrm{OH}$ with two carboxylates at axial and equatorial positions and the coordination number is raised to five as the methanol occupies the apical position of the trigonal bipyramid ${ }^{33}$. A cyclic hexamer structure is observed in ethyldiphenyltin- (Figure 5) and diphenylpropyltin(IV) acetate (Figure 6), with the electronegative oxygen atoms occupying the apical positions and the phenyl and ethyl or propyl groups lying in the equatorial plane. The Sn-O bond lengths are observed in the ranges from $2.103 \AA$ to $2.394 \AA$ for ethyldiphenyltin derivative and $2.200 \AA$ to $2.314 \AA$, indicating the asymmetric bonding in each tin centre ${ }^{21}$.

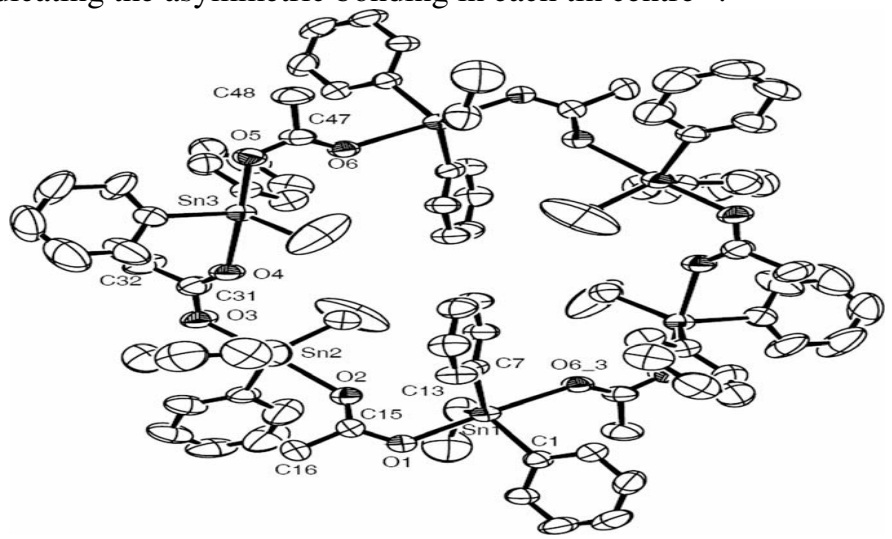

Figure 5. Molecular structure of complex ethyldiphenyltin acetate $\left[\mathrm{EtPh}_{2} \mathrm{SnOC}(\mathrm{O}) \mathrm{CH}_{3}\right]$ Ellipsoids represent $30 \%$ probability levels

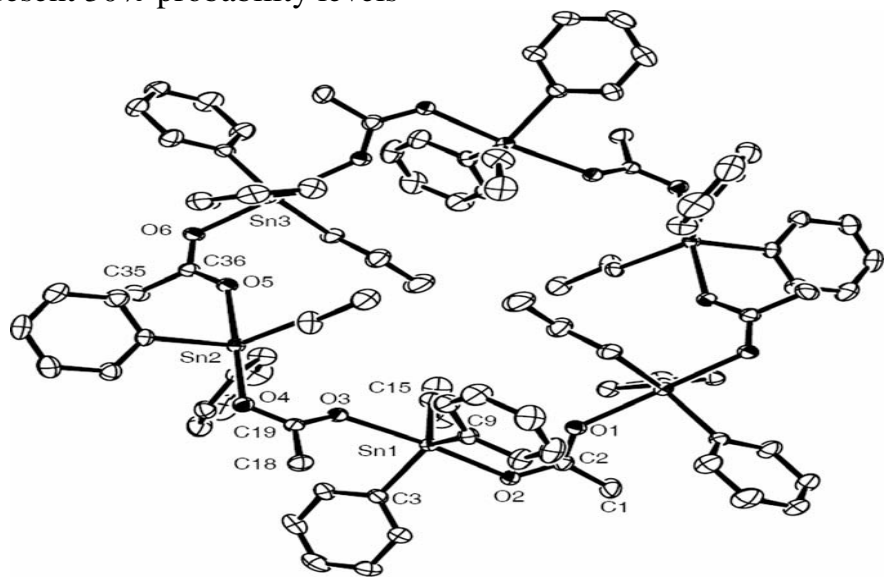

Figure 6. Molecular structure of complex diphenylpropyltin(IV) acetate $\left[\mathrm{Ph} 2 \mathrm{PrSnOC}(\mathrm{O}) \mathrm{CH}_{3}\right]$. Ellipsoids represent $50 \%$ probability levels 
The geometry at the $\mathrm{Sn}$ atom is suggested as intermediate between square pyramidal and cis-trigonal bipyramidal in triphenyl meclofenamic complex, $\left[\mathrm{Ph}_{3} \mathrm{Sn}[(\mathrm{mef})]_{3}\right.$ described by Demertzi et al., ${ }^{6}$. In this complex carboxylate group acts as an anisobidentate chelating ligand $\left(\mathrm{Sn}_{2} \ldots \mathrm{O}\right.$ (1) 2.079(3) $\left.\mathrm{A}, \mathrm{Sn} . . . \mathrm{O}(2) 2.629(4) \AA\right)$ and spans equatorial and axial sites. A 1D helical chain (Figure 7) and 1D polymeric chain structure (Figure 8) is described in triphenyltin- and trimethyltin(IV) derivative of 6-chloro-3-pyridineacetic acid respectively, with a trigonal bipyramidal geometry at each tin centre.

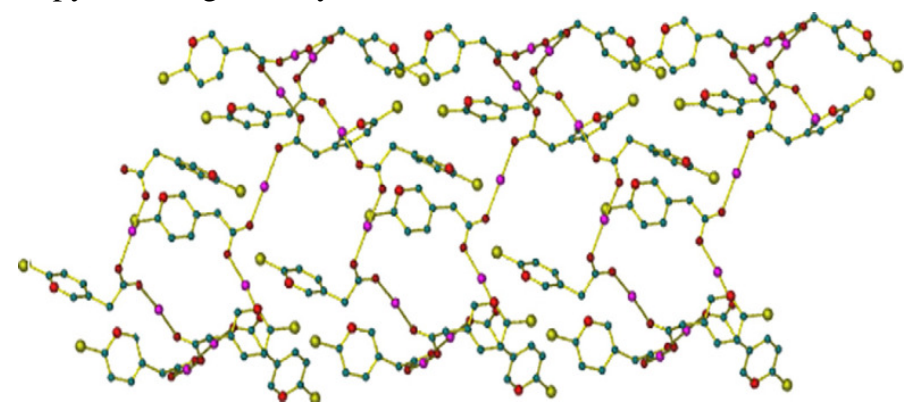

Figure 7. The 1D spring-like helical chain structure of complex $\left\{\left(\mathrm{Ph}_{3} \mathrm{Sn}\right)[(\mathrm{COO})\right.$ $\left.\left.\left(\mathrm{CH}_{2} \mathrm{C}_{5} \mathrm{H}_{3} \mathrm{NCl}\right)\right]\right\}_{\mathrm{n}}$ (the phenyl groups are omitted for clarity)

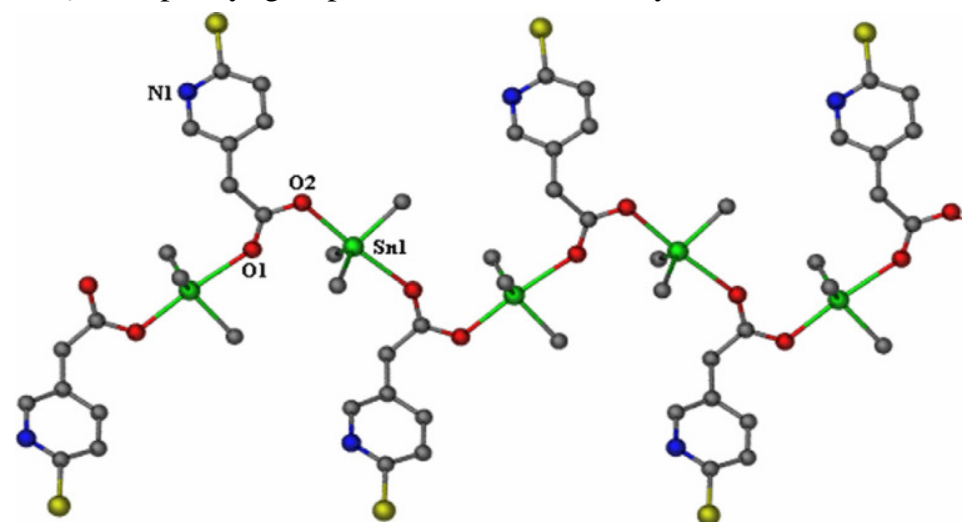

Figure 8. The 1D infinite zigzag chain structure of complex $\left\{\left(\mathrm{Me}_{3} \mathrm{Sn}\right)[(\mathrm{COO})\right.$ $\left.\left.\left(\mathrm{CH}_{2} \mathrm{C}_{5} \mathrm{H}_{3} \mathrm{NCl}\right)\right]\right\}_{\mathrm{n}}$

In complex $\left\{\left(\mathrm{Ph}_{3} \mathrm{Sn}\right)\left[(\mathrm{COO})\left(\mathrm{CH}_{2} \mathrm{C}_{5} \mathrm{H}_{3} \mathrm{NCl}\right)\right]\right\}_{\mathrm{n}}$ the coordinated oxygen atoms occupy the axial sites $(\mathrm{Sn}-\mathrm{O}=2.18(3)-2.32(4) \AA)$ and the $\mathrm{O}-\mathrm{Sn}-\mathrm{O}$ angles at $173.8(15)-179.3(15)^{\circ}$, indicating the presence of a linear arrangements ${ }^{34}$. A monomeric trans $\mathrm{R}_{3} \mathrm{SnO}$ structural moiety (Figure 9) is suggested in tribenzyltin(IV) complex, $\mathrm{Bz}_{3} \mathrm{Sn}\left[\mathrm{O}_{2} \mathrm{CC}_{6} \mathrm{H}_{4}\left\{\mathrm{~N}=\mathrm{N}\left(\mathrm{C}_{6} \mathrm{H}_{3}-4-\right.\right.\right.$ $\left.\left.\left.\mathrm{OH}\left(\mathrm{C}(\mathrm{H})=\mathrm{NC}_{6} \mathrm{H}_{4} \mathrm{Cl}-4\right)\right)\right\}-o\right]\left(\mathrm{H}_{2} \mathrm{O}\right)$.

In this complex, tin atom has a distorted trigonal-bipyramidal geometry with equatorial benzyl groups $(\mathrm{Sn}-\mathrm{C}(21)=2.150(2) \AA, \mathrm{Sn}-\mathrm{C}(28)=2.148(2) \AA, \mathrm{Sn}-\mathrm{C}(35)=2.143(2) \AA$; $\left.\mathrm{C}(21)-\mathrm{Sn}-\mathrm{C}(28)=118.19(9)^{\circ}, \mathrm{C}(21)-\mathrm{Sn}-\mathrm{C}(35)=116.35(9)^{\circ}, \mathrm{C}(28)-\mathrm{Sn}-\mathrm{C}(35)=123.18(9)^{\circ}\right)$ and the axial positions occupied by an $\mathrm{O}$ atom from the carboxylate ligand $(\mathrm{Sn}-\mathrm{O}(1)=$ $2.150(1) \AA$ A $\quad \mathrm{O}(1)-\mathrm{Sn}-\mathrm{C}(21)=89.12(8)^{\circ}, \quad \mathrm{O}(1)-\mathrm{Sn}-\mathrm{C}(28)=96.40(8)^{\circ}, \quad \mathrm{O}(1)-\mathrm{Sn}-\mathrm{C}(35)=$ $99.12(7))^{\circ}$ and the $\mathrm{O}$ atom from the water ligand $(\mathrm{Sn}-\mathrm{O}(4)=2.399(2) \AA ; \mathrm{O}(1)-\mathrm{Sn}-\mathrm{O}(4)$ $\left.173.58(6)^{\circ}\right)$. The carbonyl $\mathrm{O}$ atom of the carboxylate ligand also coordinates very weakly to the $\mathrm{Sn}$ atom with long $\mathrm{Sn} . . \mathrm{O}(2)$ distances of 3.056(2) $\AA^{35}$. 


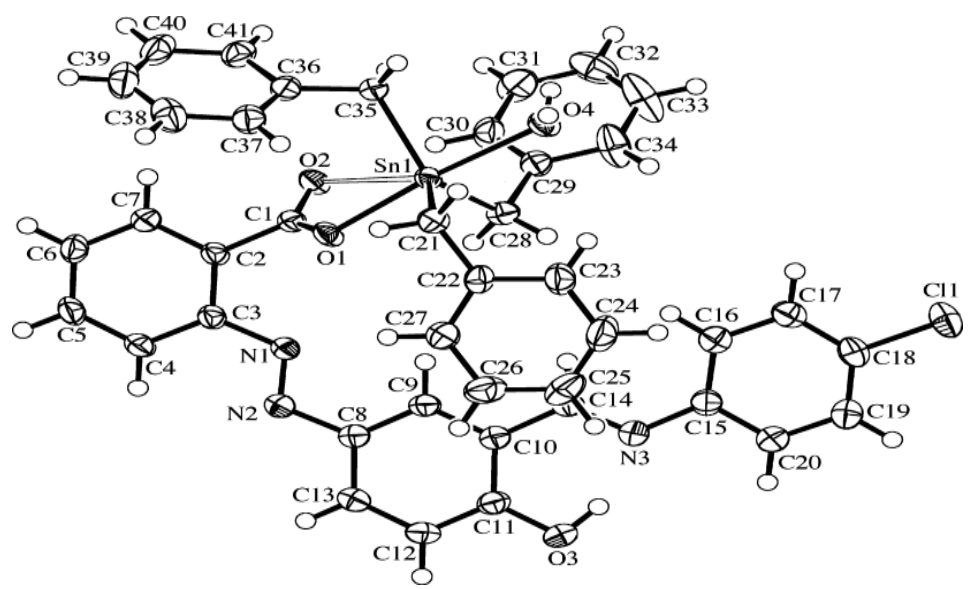

Figure 9. The molecular structure of $\mathrm{Bz}_{3} \mathrm{Sn}\left[\mathrm{O}_{2} \mathrm{CC}_{6} \mathrm{H}_{4}\left\{\mathrm{~N}=\mathrm{N}\left(\mathrm{C}_{6} \mathrm{H}_{3}-4-\mathrm{OH}\left(\mathrm{C}(\mathrm{H})=\mathrm{NC}_{6} \mathrm{H}_{4} \mathrm{Cl}\right.\right.\right.\right.$ 4)) $\}-o]\left(\mathrm{H}_{2} \mathrm{O}\right)$ showing the atom-labelling scheme (50\% probability ellipsoids)

The molecular structure of trimethyltin(IV) 2,3-methylenedioxy benzoate ${ }^{22}$ and tributyl $\{\beta-\{[(E)-1-(2 \text { hydroxyphenyl) methylidene }] \text { amino }\} \text { ropionate }\} \text { tin(IV) })^{32}$ are shown to be a polymeric chain structure having Monoclinic crystal system with space group $P 2{ }_{1} / c(a=$ 10.7071(7), $b=9.9808(10), c=12.4504(8) \AA ; \alpha=\gamma=90, \beta=111.976(7)^{\circ} ; Z=4 ; D_{c}\left(g^{\circ} c^{-3}\right)=$ 1.771) (Figure 10) and $P 2_{1} / n(a=13.7830(3), b=9.9060(2), c=17.7972(4) \AA ; \alpha=\gamma=90, \beta=$ $\left.109.616(1))^{\circ} ; \mathrm{Z}=4 ; \mathrm{D}_{\mathrm{c}}\left(\mathrm{g} \mathrm{cm}^{-3}\right)=1.399\right)$ (Figure 11), respectively. The geometry of the tin is described as a trigonal bipyramidal geometry with oxygen atoms of carboxylate group in the apical positions $(\mathrm{Sn} 1-\mathrm{O} 1=2.376(3), \mathrm{Sn} 1-\mathrm{O} 2=2.217(3) \AA$ ) and the 3 methyl groups in the equatorial positions (C11-Sn1= 2.122(5), C10-Sn1 2.122(6), C9-Sn1 2.128(5) $\AA$ ) in aforementioned complex. While in tributyl $\{\beta-\{[(E)-1$-(2hydroxyphenyl)methylidene $]$ amino $\}$ ropionate tin(IV), the coordination sphere of the $\mathrm{Sn}$-atom is trans- $-\mathrm{Bu}_{3} \mathrm{SnO}_{2}$ in trigonal bipyramidal geometry with three butyl groups at equatorial position $(\mathrm{Sn}-\mathrm{C}(11)=$ $2.147(2), \mathrm{Sn}-\mathrm{C}(15)=2.151(2), \mathrm{Sn}-\mathrm{C}(19)=2.140(2) \AA)$ and two carboxylate $\mathrm{O}$ atoms at axial positions $\left(\mathrm{Sn}-\mathrm{O}(1)=2.460(2), \mathrm{Sn}-\mathrm{O}(2)^{\mathrm{i}}=2.181(2), \mathrm{Sn} \ldots \mathrm{O}(1)^{\mathrm{i}}=3.043(2) \AA\right)$.

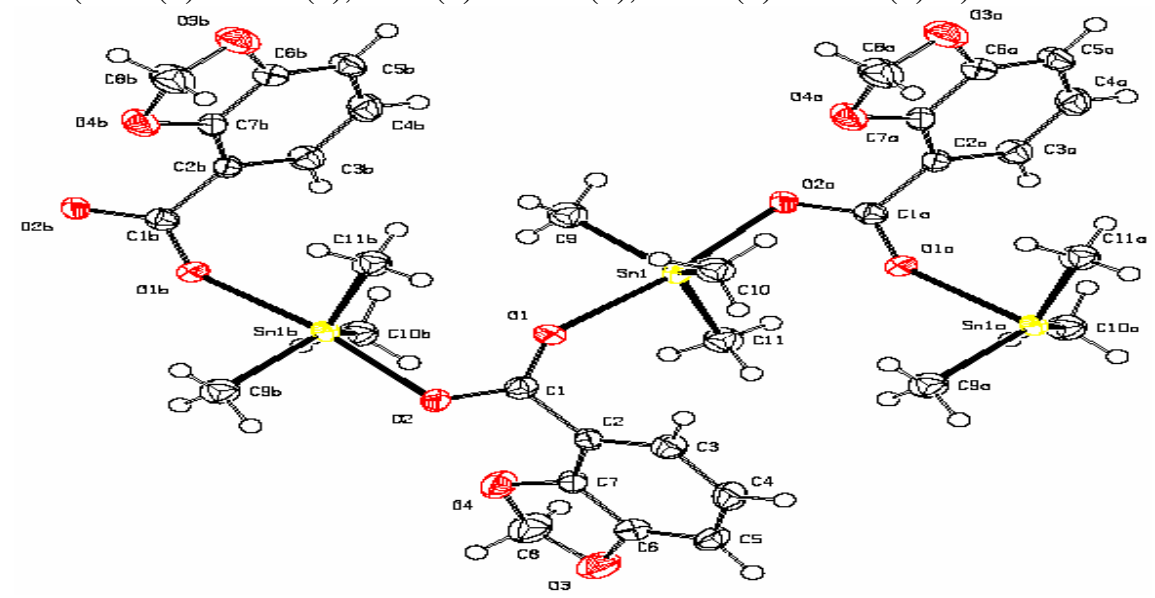

Figure 10. An ORTEP ${ }^{18}$ drawing of complex trimethyltin(IV) 2,3-methylenedioxy benzoate. Displacement ellipsoids are drawn at 50\% probability level 


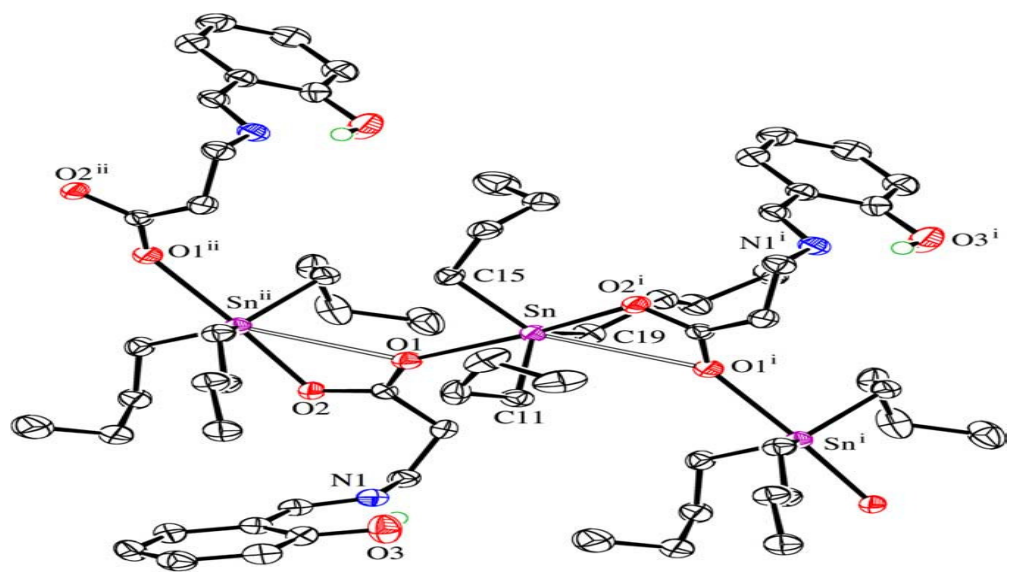

Figure 11. A three-unit segment of the polymeric tributyl $\{\beta-\{[(E)-1-(2$ hydroxyphenyl $)$ methylidene]amino \} propionato tin(IV) (50\% probability ellipsoids)

Tian et al., ${ }^{36}$ have studied X-ray crystal structure of organotindinuclear complex, (HL) $\mathrm{SnPh}_{3} \bullet \mathrm{Ph}_{2} \mathrm{SnL}\left[\mathrm{L}=2-\mathrm{O}-3,5-\mathrm{Br}_{2} \mathrm{C}_{6} \mathrm{H}_{3} \mathrm{CH}=\mathrm{NCH}(i\right.$-Pr)COO] derived from triphenyltin chloride and potassium $\mathrm{N}$-[(3,5-dibromo-2-hydroxyl-phenyl)methylene] valinate in benzene. The coordination spheres of tin atoms are trans- $\mathrm{O}_{2} \mathrm{Sn} 1 \mathrm{C}_{2} \mathrm{~N}$ and trans- $\mathrm{O}_{2} \mathrm{Sn} 2 \mathrm{C}_{3}$ in distorted pentagonal bipyramidal geometry (Figure 12).

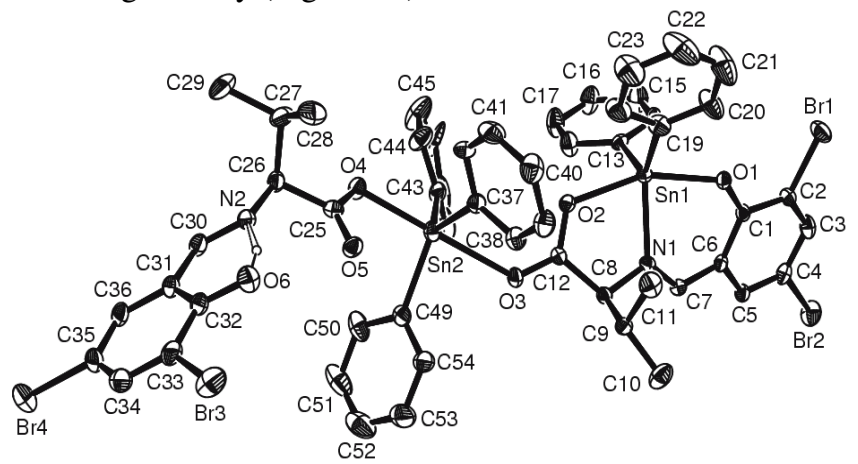

Figure 12. The molecular structure of (HL) $\mathrm{SnPh}_{3} \bullet \mathrm{Ph}_{2} \mathrm{SnL}$

In $\mathrm{O}_{2} \mathrm{Sn} 1 \mathrm{C}_{2} \mathrm{~N}$ coordination sphere, two phenyl groups and imino $\mathrm{N} 1$ atom occupied the equatorial positions and a phenoxide $\mathrm{O} 1$ and a carboxylate oxygen $\mathrm{O} 2$ atom occupied the axial positions $\left(\mathrm{O} 1-\mathrm{Sn} 1-\mathrm{O} 2=156.92(16)^{0}\right)$ and while three phenyl groups occupied the equatorial positions around $\mathrm{Sn} 2$ atom and the carbonyl oxygen $\mathrm{O} 3$ atom of bridging carboxylate group and the carboxylate group oxygen $\mathrm{O} 4$ atom of the other ligand occupied the axial positions (O3-Sn2-O4 178.35(16) ${ }^{\circ}$ ).

\section{Four coordinated complexes}

A four coordinated complexes are observed with the monodentate bonding of the carboxylate group to the tin atom in distorted tetrahedral geometry. Yip et al., ${ }^{19}$ have synthesized Bis[triphenyltin(IV)] succinate by reacting triphenyltin(IV) hydroxide with substituting succinic acid and observed a four coordinated complex with monoclinic crystal system having space group $P 2_{l} / n$ and $\mathrm{a}=9.5257(7), \mathrm{b}=19.2278(14), \mathrm{c}==9.7482(7) \AA$; $\alpha=\gamma=90, \beta=102.9070(10)^{0}, Z=4$ (Figure 13). 


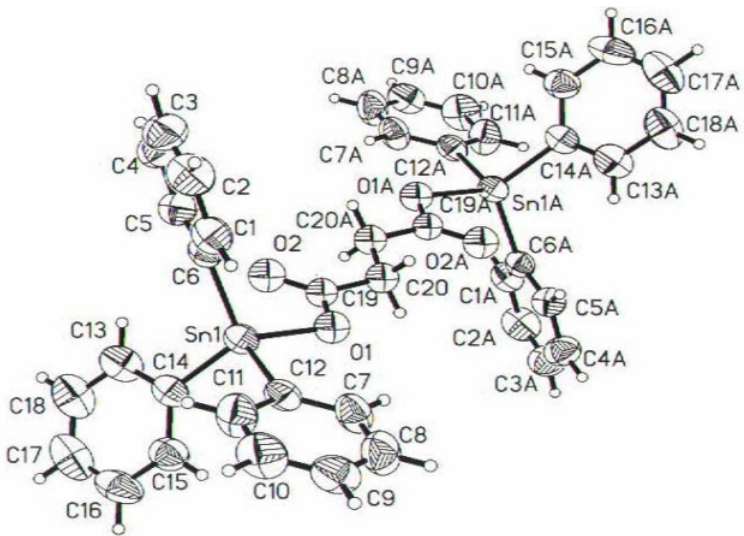

Figure 13. ORTEP plot for complex bis[triphenyltin(IV)] succinate at 50\% probability level with atom numbering scheme

A four coordinated trimethyltin(IV) complex, (3-amino-4-chlorobenzoato)trimethyltin (IV) is also synthesized by Rehman et al. ${ }^{20}$ in which three methyl groups ( $\mathrm{Sn}-\mathrm{C}=2.118$ (2)2.119 (2) $\AA$ ) and one $\mathrm{O}$ atom $(\mathrm{Sn}-\mathrm{O}=2.0804(12) \AA)$ is bonded to the tin atom in distorted tetrahedral geometry (Figure 14). The complex is crystallize in monoclinic crystal system with space group $P 2{ }_{I} / c$ and $\mathrm{a}=11.9077$ (7), $\mathrm{b}=9.1237(5), \mathrm{c}=12.6554$ (7) $\AA$; $\beta=113.086(1)^{0}$, $\mathrm{Z}=4$. Furtheremore the crystal structure of this complex contains centrosymmetric dimmers formed via intermolecular N-H....O hydrogen bonds (Figure 15).

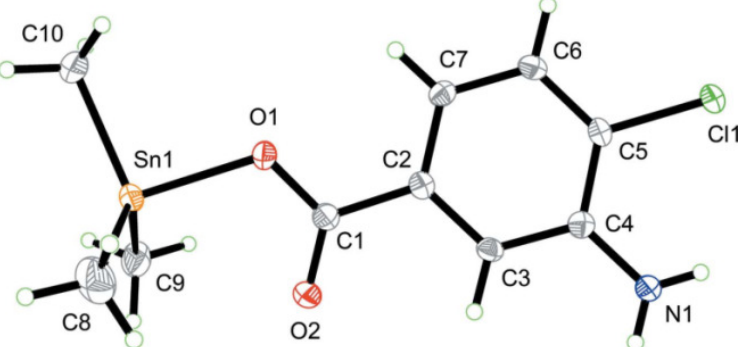

Figure 14. The molecular structure of (3-amino-4-chlorobenzoato)trimethyltin(IV) with displacement ellipsoids drawn at the $50 \%$ probability level. $\mathrm{H}$ atoms are shown as spheres of arbitrary radii

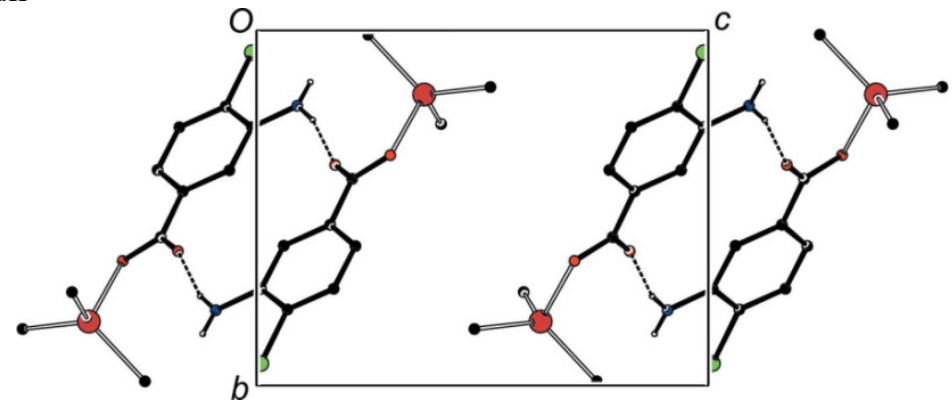

Figure 15. Centrosymmetric immers of (3-amino-4-chlorobenzoato)trimethyltin(IV), formed through intermolecular hydrogen bonding (dashed lines). $\mathrm{H}$ atoms not involved in hydrogen bonding have been omitted for clarity 


\section{Distannoxanes}

In diorganotin(IV) complexes, distannoxanes are observed with five or six coordinated geometry ${ }^{6,37-40}$. A centrosymmetric dimer of an oxoditin(IV) complex, tetrabutylbis- $(3,4-$ dichlorophenylacetato)distannoxane, with monodentate and bridging bidentate carboxylate ligands is described by M.A. Saeed et al. The central $\mathrm{Sn}_{2} \mathrm{O}_{2}$ core is fused with 2 sixmembered rings $\left(\mathrm{Sn}_{2} \mathrm{O}_{3} \mathrm{C}_{1}\right)$ having $\mathrm{O}$ and $\mathrm{C}$ atoms of the ligand that show different modes of coordination with $\mathrm{Sn}$ (Figure 16).

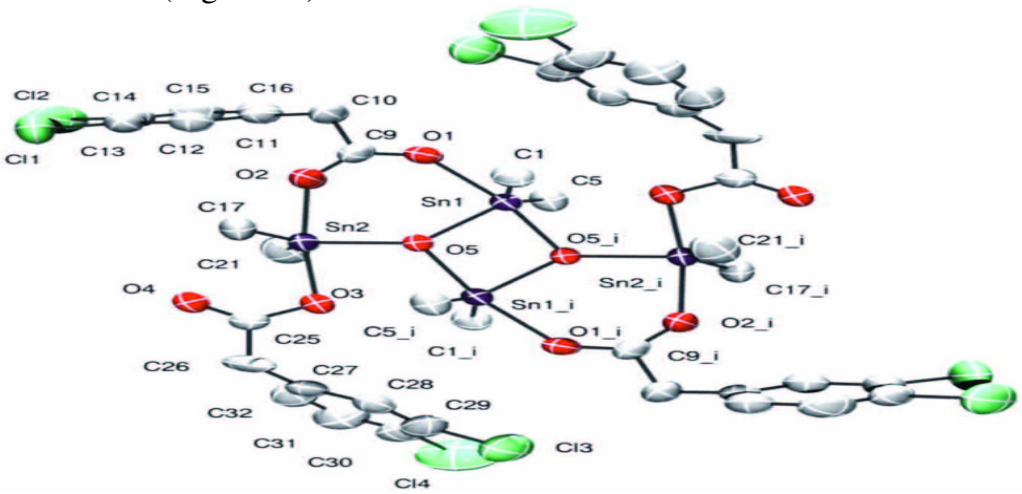

Figure 16. The ORTEP-POV molecular structure of complex, tetrabutylbis(3,4dichlorophenylacetato)distannoxane drawn at the $30 \%$ probability level. For clarity, only the connecting $\mathrm{C}$ atoms of the $n$-butyl groups are shown

The coordination sphere of endocyclic and exocyclic $\mathrm{Sn}$ atoms are $\mathrm{C}_{2} \mathrm{SnO}_{3}$ in distorted trigonal-bipyramidal geometry with $\mathrm{Sn}-\mathrm{C}$ distances lying in the range of 2.089(11)2.181(14) $\AA$, while $\mathrm{Sn}-\mathrm{O}$ distances are in the range of 2.054(6)-2.257(9) $\AA^{41}$.

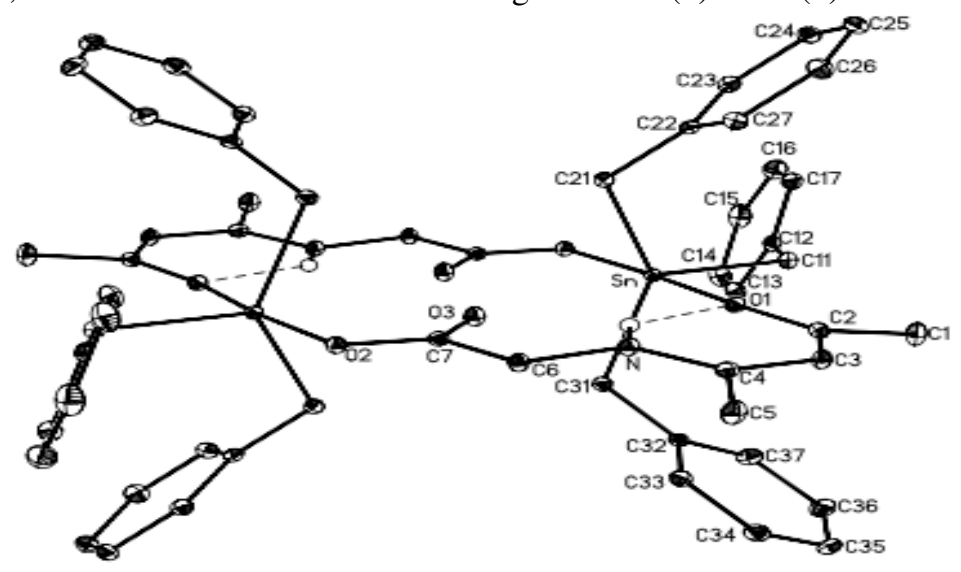

Figure 17. Molecular structure of tribenzyl $\{2-\{[(2 Z)-3$-hydroxy-1methyl-2-butenylidene $]$ amino \}acetato\}tin(IV)

A centrosymmetric dimer is also observed in tribenzyl $\{2-\{[(2 Z)-3$-hydroxy-1methyl-2butenylidene]amino $\}$ acetato $\}$ tin(IV) with a trigonalbipyramidal configuration at each tin atom (Figure 17). The three benzyl groups occupied the equatorial positions $(\mathrm{Sn}-\mathrm{C}(21)=$ $2.1583(15), \mathrm{Sn}-\mathrm{C}(31)=2.1610(15), \mathrm{Sn}-\mathrm{C}(11)=2.1805(17) \AA$ ) while the axial positions are occupied by a carboxylate oxygen from one ligand molecule $\mathrm{O}(2)(\mathrm{Sn}-\mathrm{O}(2) \# 1=2.2166(11) \AA)$ 
and the alkoxy oxygen, $\mathrm{O}(1)(\mathrm{Sn}-\mathrm{O}(1)=2.3712(11) \AA)$, of the second ligand molecule ${ }^{42}$. A ladder-like structure is found in a centrosymmetric dimer distannoxane, $\left[\mathrm{Me}_{2}(\mathrm{Meclo})\right.$ $\left.\mathrm{SnOSn}(\mathrm{Meclo}) \mathrm{Me}_{2}\right]_{2}$ complex due to the fusion of a central $\mathrm{Sn}_{2} \mathrm{O}_{2}$ core with a outer $\mathrm{Sn}_{2} \mathrm{O}_{2}$ rings (Figure 18). The exocyclic $\mathrm{Sn}$ atom is six coordinated and shows distorted octahedral geometry. The endocyclic Sn atom is five coordinated and described as intermediate between square pyramidal and cis-trigonal bipyramida ${ }^{16}$. A drum structure is observed in $[\mathrm{PhSn}(\mathrm{O})$ (COO) $\left.\left(\mathrm{CH}_{2} \mathrm{C}_{5} \mathrm{H}_{3} \mathrm{NCl}\right)\right]_{6}$ complex with a $\mathrm{Sn}_{6} \mathrm{O}_{6}$ central stannoxane core which contains two puckered six-membered $\left[\mathrm{Sn}_{3}\left(\mu_{3}-\mathrm{O}\right)_{3}\right]$ rings as its top and bottom faces and the side face of the drum is characterized by six puckered four-membered $\left[\mathrm{Sn}_{2}\left(\mu_{3}-\mathrm{O}\right)_{2}\right] \operatorname{rings}^{34}$.

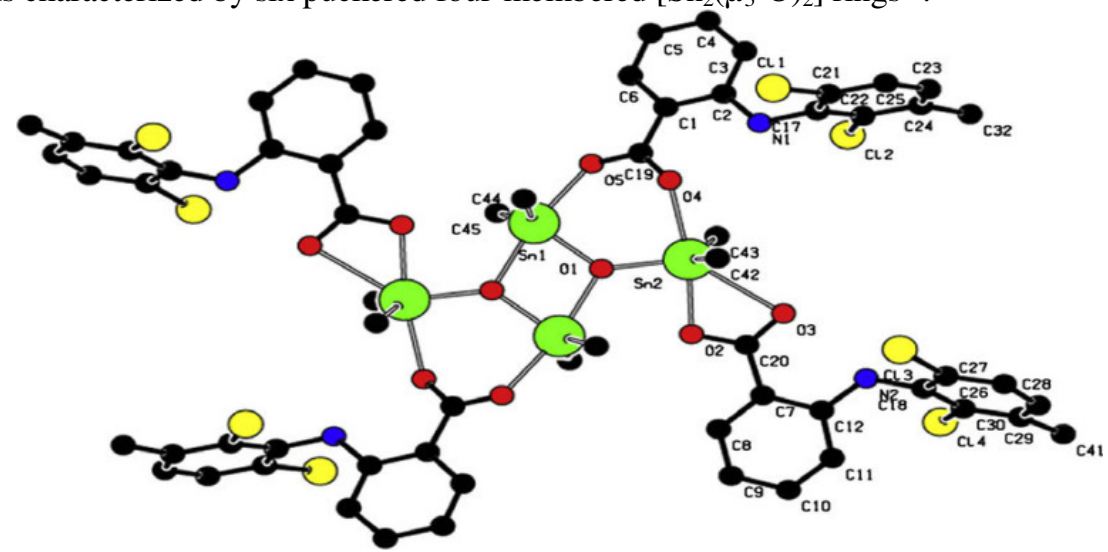

Figure 18. Molecular structure of complex $\left[\mathrm{Me}_{2}(\mathrm{Meclo}) \mathrm{SnOSn}(\mathrm{Meclo}) \mathrm{Me}_{2}\right]_{2}$

Baul et al., ${ }^{32}$ have investigated the crystal structure of dibutyl $\{\beta-\{[(E)-1-(2-$ hydroxyphenyl)ethylidene]- amino $\}$ ropionate $\}$ tin(IV) (Figure 19) and dibutyl $\{\beta-\{[(E)-1-$ (2-hydroxy-3 methylphenyl)ethylidene]amino $\}$ ropionate $\} \operatorname{tin}(\mathrm{IV})$ (Figure 20) and found a centrosymmetric tetranuclear complexes containing a planar $\mathrm{Sn}_{4} \mathrm{O}_{2}$ core in which two $\mu_{3}-$ oxo $O$-atoms connect an $\mathrm{Sn}_{2} \mathrm{O}_{2}$ ring to two exocyclic $\mathrm{Sn}$-atoms. Both the complexes have six coordinations at each tin atom and crystallize in the triclinic crystal system with space group $P 1$ and $\mathrm{a}=12.475(1), \mathrm{b}=13.574(1), \mathrm{c}=14.212(1) \AA ; \alpha=94.149(5), \beta=113.754(5), \gamma=$ 109.696(5); $\mathrm{Z}=1$ for fore mentioned complex and $\mathrm{a}=13.0368(3), \mathrm{b}=13.6627(3), \mathrm{c}=$ 14.7318(3) $\AA$; $\alpha=113.936(1), \beta=102.200(1), \gamma=108.279(1)^{\circ} ; Z=1$ for dibutyl $\{\beta-\{[(E)-1-$ (2-hydroxy-3 methylphenyl)ethylidene]amino $\}$ ropionate $\} \operatorname{tin}(\mathrm{IV})$.

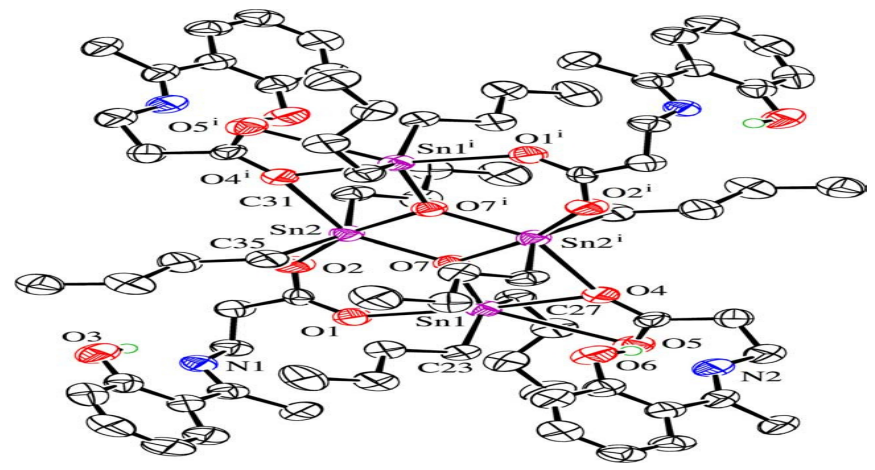

Figure 19. Molecular structure of complex dibutyl $\{\beta-\{[(E)-1$-(2-hydroxyphenyl)ethylidene]- amino $\}$ ropionate $\} \operatorname{tin}(\mathrm{IV})$ (50\% probabilityellipsoids) 


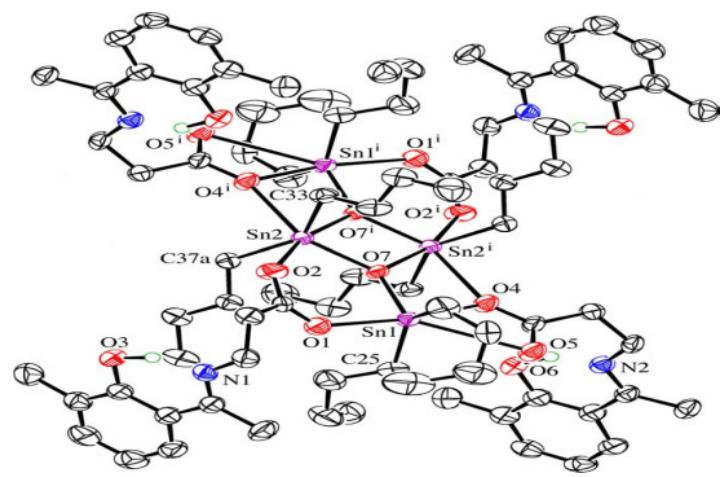

Figure 20. Molecular structure of complex dibutyl $\{\beta-\{[(E)-1-(2$-hydroxy-3 methylphenyl)ethylidene]amino propionato $\}$ tin(IV) $(50 \%$ probability ellipsoids)

\section{References}

1. Matela G and Aman R, Cent Eur J Chem., 2012, 10(1), 1-15; DOI:10.2478/s11532011-0107-6

2. Aman R, Matela G, Sharma C and Chaudhary S, Arab J Chem., 2015, 8, 698-705; DOI:10.1016/j.arabic.2014.05.005

3. Tian L, Sun Y, Li H, Zheng X, Cheng Y, Liu X and Qian B, J Inorg Biochem., 2005, 99(8), 1646-1652; DOI:10.1016/j.jinorgbio.2005.05.006

4. Li J, Zhao G, Xiong C and Yongqiang M, Synth React Inorg Met Org Chem., 2001, 31(1), 85-93; DOI:10.1081/SIM-100001934

5. Shahid K, Ali S, Shahzadi S, Badshah A, Khan K M and Maharvi G M, Synth React Inorg Met Org Chem., 2003, 33(7), 1221-1235; DOI:10.1081/SIM-120023490

6. Sun M L, Ruan B F, Zhang Q, Liu Z D, Li S L, Wu J Y, Jin B K, Yang J X, Zhang S Y and Tian Y P, J Organomet Chem., 2011, 696(20), 3180-3185;

DOI:10.1016/j.jorganchem.2011.06.045

7. Demertzi D K, Dokorou V, Primikiri A, Vargas R, Silvestru C, Russo U and Demertzis M A, J Inorg Biochem., 2009, 103, 738-744; DOI:10.1016/j.jinorgbio.2009.01.014

8. Cai S L, Chen Y, Sun W X, Li H, Chen Y and Yuan S S, Bioorg Med Chem Lett., 2010, 20(19), 5649-5652; DOI:10.1016/j.bmcl.2010.08.034

9. Chandrasekhar V, Thirumoorthi R, Metre R K and Mahanti B, J Organomet Chem., 2011, 696(2), 600-606; DOI:10.1016/j.jorganchem.2010.09.032

10. Du D, Jiang Z, Liu C, Sakho A M, Zhu D and Xu L, J Organomet Chem., 2011, 696(13), 2549-2558; DOI:10.1016/j.jorganchem.2011.03.048

11. Benetollo F, Lobbia G G, Mancini M, Pellei M and Santini C, J Organomet Chem., 2005, 690(8), 1994-2001; DOI:10.1016/j.jorganchem.2004.11.034

12. Baul T S B, Dutta S, Rivarola E, Butcher R and Smith F E, J Organomet Chem., 2002, 654(1-2), 100-108; DOI:10.1016/S0022-328X(02)01387-6

13. Rehman S, Ali S, Badshah A, Malik A, Ahmed E, Jin G-X and Tiekink E R T, Appl Organomet Chem., 2004, 18(8), 401-408; DOI:10.1002/aoc.687

14. Ma C, Wang $\mathrm{Y}$ and Zhang $\mathrm{R}$, Inorg Chim Acta, 2009, 362, 4137-4144; DOI:10.1016/j.ica.2009.06.016

15. Chandrasekhar V, Nagendran S and Baskar V, Coord Chem Rev., 2002, 235(1-2), 1-52; DOI:10.1016/S0010-8545(02)00178-9 
16. Baul T S B, Paul A and Linden A, J Organomet Chem., 2012, 696(26), 4229-4235; DOI:10.1016/j.jorganchem.2011.09.018

17. Du D, Jiang Z, Liu C, Sakho A M, Zhu D and Xu L, J Organomet Chem., 2011, 696(13), 2549-2558; DOI:10.1016/j.jorganchem.2011.03.048

18. Sarma M S, Saha A and Roy A, Appl Organomet Chem., 2008, 22(7), 369-377; DOI:10.1002/aoc.1403

19. Salam M A, Affan M A, Ahmad F B, Jusoh I, Shamsuddin M B, Yamin B and Farina, Y, J Organomet Chem., 2012, 696, 4202-4206; DOI:10.1016/j.jorganchem.2011.09.013

20. Yip F W, Farina Y, Teoh S G, Hussain S H I, Yamin B M, Baba I and Ali A M, Malays J Pharm Sci., 2006, 4, 33-47.

21. Rehman A, Ali S, Helliwell M and Shahzadi S, Acta Cryst., 2006, E62, m1778-1779; DOI:10.1107/S1600536806025517

22. Amini M M, Azadmehr A, Alijani V, Khavasi H R, Hajiashrafi T and Kharat A N, Inorg Chim Acta, 2009, 362, 355-360; DOI:10.1016/j.ica.2008.04.009

23. Hussain M, Hanif M, Ali S, Shahzadi S and Evans H S, Turk J Chem., 2008, 32, 25.

24. Rehman S, Ali S, Shahzadi S, Malik A and Ahmed E, Turk J Chem., 2007, 31, 371.

25. Win Y F, Teoh S G, Ha S T, Ong L G A and Muhammad T S T, Int J Phys Sci., 2011, 6(6), 1463; DOI:10.5897/IJPS11.039

26. Sun M L, Ruan B F, Zhang Q, Liu Z D, Li S L, Wu J Y, Jin B K, Yang J X, Zhang S Y and Tian Y P, J Organomet Chem., 2011, 696(20), 3180-3185;

DOI:10.1016/j.jorganchem.2011.06.045

27. Ruiz S G, Torres J C, Prashar S, Fajardo M, Zizak Z, Juranic Z D and Kaluderovic G N, J Organomet Chem., 2011, 696(18), 3023-3028;

DOI:10.1016/j.jorganchem.2011.06.002

28. Shukla S K, Tiwari V K, Rani S and Tiwari I C, J Med Chem Lett., 2011, 1, 10.

29. Rehman S U, Ali S, Shahzadi, S, Malik A and Ahmed E, Turk J Chem., 2007, 31, 371-387.

30. Ahmad S, Ali S, Shahzadi S, Ahmed F and Khan K M, Turk J Chem., 2005, 29, 299.

31. Azadmeher A, Amini M M, Hadipour N, Khavasi H R, Fun H K and Chen C J, Appl Organomet Chem., 2008, 22(1), 19-24; DOI:10.1002/aoc.1343

32. Rehman S U, Ly H V, Ali S, Badshah A and Parvez M, ActaCryst., 2004, E60, m1144-m1146; DOI:10.1107/S1600536804017039

33. Baul T S B, Masharing C, Basu S, Rivarola E, Holcapek M, Jirasko R, Lycka, A, Vos de D and Linden A, J Organomet Chem., 2006, 691(5), 952-965; DOI:10.1016/j.jorganchem.2005.10.057

34. Amini M M, Azadmeher A, Khavasi H R and Ng S W, J Organomet Chem., 2007, 692(18), 3922-3930; DOI:10.1016/j.jorganchem.2007.05.049

35. Zhang J H, Zhang R F, Ma C L, Wang D Q and Wang H Z, Polyhedron, 2011, 30(4), 624-631; DOI:10.1016/j.poly.2010.11.035

36. Baul T S B, Singh K S, Linden A, Song X and Eng G, Polyhedron, 2006, 25(17), 3441-3448; DOI:10.1016/j.poly.2006.06.026

37. Tian L J, Sun Y X, Yang G M, Qian B C and Shang Z C, Chin Chem Lett., 2005, 16(12), 1584.

38. Ahmad A, Khan A, Ali S and Parvez M, ActaCryst., 2006, E62, m1088-m1090; DOI:10.1107/S1600536806014115

39. Ahmad A, Khan A, Ali S and Parvez M, ActaCryst., 2006, E62, m1167-m1169; DOI:10.1107/S1600536806014966 
40. Rehman A, Shahzadi S, Ali S and Helliwell M, ActaCryst., 2006, E62, m1734m1736; DOI:10.1107/S1600536806024627

41. Parvez M, Rehman S, Shahid K, Ali S and Mazhar M, ActaCryst., 2004, E60, m1465m1467; DOI:10.1107/S1600536804022950

42. Saeed M A, Rauf M K, Din I U, Badshah A, Akhtar M Z and Mirza B, Turk J Chem., 2010, 34, 109.

43. Baul T S B, Masharing C, Rivarola E, Smith F E and Butcher R, Struct Chem., 2007, 18(2), 231; DOI:10.1007/s11224-006-9085-2 